\title{
Apoproteins: determinants of lipoprotein metabolism and indices of coronary risk
}

\author{
GILBERT THOMPSON \\ From the MRC Lipoprotein Team, Hammersmith Hospital, London
}

It soon became obvious after the introduction of lipoprotein phenotyping by Fredrickson $e t a^{1}$ that alterations in plasma lipids are largely due to inherited or acquired abnormalities of the lipoproteins on which they are transported rather than to disorders of the lipids themselves. Furthermore, it is now apparent that disturbances of lipoprotein metabolism can often be explained by alterations in the structure or function of the protein moiety, known collectively as apolipoproteins or apoproteins; these are designated individually by the abbreviation apo followed by an alphabetical suffix, which in some instances is further qualified numerically (for example, apoA-I, $\mathrm{apoB}_{48}$ ). Hence the current trend is to analyse apoproteins as well as lipids when investigating subjects with hyperlipidaemia or attempting to detect them by screening.

Apoproteins have three main functions: they help solubilise cholesterol and triglyceride by interacting with the other major class of lipids found in lipoproteins-namely, phospholipids; they regulate the reaction of these lipids with enzymes such as lecithin: cholesterol acyl transferase (LCAT) and lipoprotein lipase; and they bind to cell surface receptors and thus determine the sites of uptake and rates of degradation of other lipoprotein constituents, notably cholesterol. A brief description of lipoprotein metabolism at this stage may help the reader appreciate the mechanistic implications of quantitative or qualitative changes in individual apoproteins.

\section{Role of apoproteins in lipoprotein metabolism}

The major steps involved in lipoprotein formation and removal are detailed in the Figure. Important sites are the small intestine, liver, and peripheral cells, including adipocytes, macrophages, and arterial smooth muscle cells, while the plasma and interstitial fluid

Requests for reprints to Dr Gilbert Thompson, MRC Lipoprotein Team, Hammersmith Hospital, Ducane Road, London W12 OHS. serve as an interconnecting transport medium. Considerable transfer and exchange of lipids takes place between the different lipoprotein classes, but there is less movement of apoproteins except for the small apoC peptides, which shuttle back and forth between triglyceride-rich lipoproteins and high density lipoprotein (HDL). Pronounced variations can occur in the lipid composition of lipoproteins in plasma, which suggests that measurement of apoprotein concentration provides a better index of the number of particles than does determination of their cholesterol or triglyceride content. In general terms apoE can be regarded as a marker for chylomicron and very low density lipoprotein (VLDL) remnants, apoB $_{100}$ for low density lipoprotein (LDL), and apoA-I for HDL. Various methods are available for measuring apoprotein concentration, as recently reviewed elsewhere, ${ }^{4}$ the two commonest being electroimmunoassay and radial immunodiffusion.

\section{Lipids, lipoproteins, and apoproteins as risk factors}

Hypercholesterolaemia and hypertriglyceridaemia have long been recognised as common accompaniments of coronary heart disease and frequently have a genetic basis. ${ }^{56}$ The predictive value of serum total cholesterol is, however, limited by the fact that it reflects the opposing influences of LDL cholesterol and HDL cholesterol, the former correlating positively and the latter negatively with coronary heart disease. ${ }^{7}$ The negative correlation between HDL and coronary heart disease appears to depend mainly on its minor subfraction, $\mathrm{HDL}_{2}$, and it has been proposed that the latter provides an even better index of risk than does total HDL. ${ }^{8}$ Analysis of the small amount of cholesterol in $\mathrm{HDL}_{2}$ can now be achieved using a relatively simple precipitation method ${ }^{9}$ but has the drawback that even slight analytical errors severely bias the estimate of risk. Thus predicting coronary heart disease by measuring the lipid components of plasma lipoproteins is becoming an increas- 


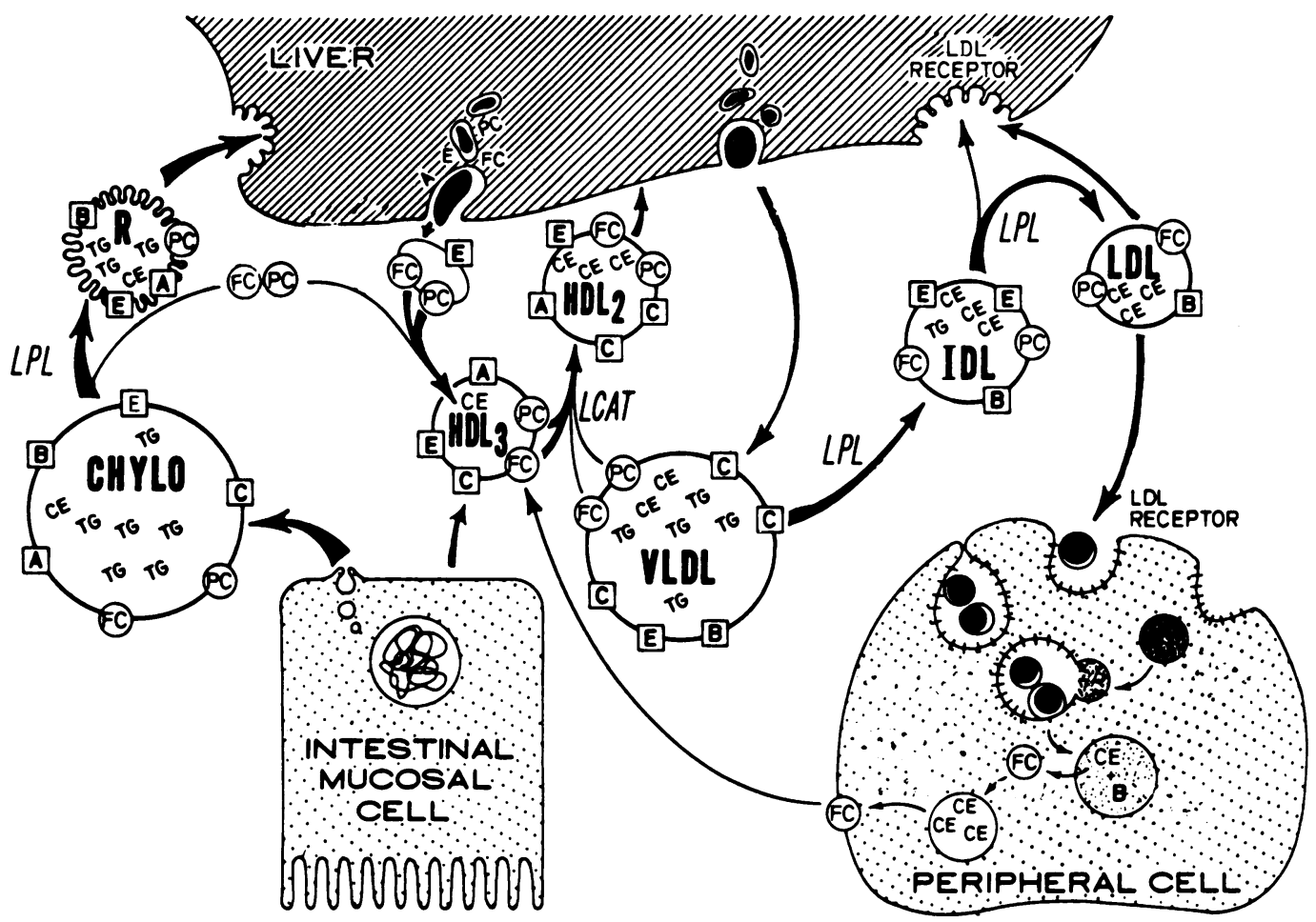

Figure Diagrammatic representation of lipoprotein metabolism after Davignon et al $.^{2} A, B, C$, and $E$ refer to the corresponding apoproteins and FC, PC, CE, and TG to free cholesterol, phospholipid, cholesterol ester, and triglyceride respectively. Chylomicrons transport dietary lipids via lymph into plasma and then get degraded to remnants (chylo and $R$ respectively) by extrahepatic lipoprotein lipase (LPL), which is activated by apoc-II. Chylomicron remnants are then taken up by hepatic receptors which recognise the apoE on their surface. Very low density lipoproteins (VLDL) carry endogenously synthesised triglyceride from the liver into plasma, where like chylomicrons they undergo partial degradation to VLDL remnants, known also as intermediate density lipoprotein $(I D L)$. The latter are then either taken up by the low density lipoprotein $(L D L)$ receptor, which recognises both the $a p o E$ and the $a p o B_{100}$ they contain (as distinct from the smaller $a p o B_{48}$ present in chylomicrons), or are further degraded to $L D L$, which contains $a p o B_{100}$ but not apoE. $L D L$ in turm undergoes catajolism via at least two major pathways, one of which is mediated by the $L D L$ receptor. ${ }^{3}$ High density lipoprotein $(H D L)$ has diverse origins, much of its lipid being derived from free cholesterol and phospholipid released during the lipolysis of chylomicrons and VLDL as well as from free cholesterol effluxing from peripheral cells, whereas its major apoprotein, apoA-I, is symthesised both in the liver and small intestine. Nascent HDL particles initially become $\mathrm{HDL}_{3}$ in plasma but eventually get converted to larger $H D L_{2}$ particles by the action of lecithin: cholesterol acyl transferase (LCAT), which is activated by apoA-I.

ingly complex but not necessarily more precise endeavour.

Recent evidence suggests that determining the number of LDL and HDL particles present in plasma by measuring the concentration of their respective apoproteins, apoB and apoA-I, discriminates better between patients with and without coronary heart disease than does quantitating the amount of cholesterol these particles carry. ${ }^{1011}$ Earlier, Avogaro et al had found a significant increase in plasma apoB concentrations and a significant decrease in plasma apoA-I concentrations in patients who had survived a myocardial infarct compared with control subjects of similar age but without electrocardiographic evidence of coronary heart disease. ${ }^{12}$ On the basis of univariate analyses these authors showed that apoprotein concentrations correlated with coronary heart disease as well as did serum lipids and better in older age groups. ${ }^{13}$ Using the preferable statistical method of multivariate analysis Whayne et al confirmed that apoB concentrations correlated better with angiographically confirmed coronary heart disease than did serum cholesterol, especially in patients with a relatively mild degree of hypercholesterolaemia. ${ }^{14}$ ApoB concentrations are higher in men than in women, whereas the reverse holds true for apoA-I, 15 and both tend to 
decrease after a myocardial infarct, so that blood should be taken either within 24 hours of its occurrence or several weeks later. ${ }^{16}$

Opinions are divided about whether apoA-I really is a better index of coronary heart disease than HDL or $\mathrm{HDL}_{2}$ cholesterol. ${ }^{101317}$ LDL-apoB concentrations, however, appear to discriminate between patients with or without coronary heart disease even when they have a normal LDL cholesterol concentration. ${ }^{18}$ If total apoB concentrations are determined in plasma by electroimmunoassay these correlate with both plasma cholesterol and triglyceride, ${ }^{14}$ the latter association presumably reflecting the amount of VLDL present, which like LDL also contains apoB. Under appropriate conditions, however, it is possible to measure LDL-apoB without interference from VLDL-apoB even in hypertriglyceridaemic plasma using radial immunodiffusion. ${ }^{19}$ Several studies have suggested that the association of hypertriglyceridaemia with coronary heart disease is not an independent one but simply reflects the inverse relation which often exists between serum triglyceride and HDL cholesterol. ${ }^{20}$ An alternative explanation has been proposed by Sniderman et al, who have shown that LDL-apoB is increased in some but not all hypertriglyceridaemic patients and have proposed that it is only those with raised LDL-apoB concentrations who are at increased risk of atherosclerosis. ${ }^{11}$ This hypothesis is currently being tested in a prospective study of subjects attending a large screening centre in London.

The propensity of patients with familial hypercholesterolaemia to develop severe premature coronary heart disease is now well established and the same applies, albeit to a lesser extent, to type III hyperlipoproteinaemia. ${ }^{21}$ Both conditions are autosomal dominantly inherited, but in type III hyperlipoproteinaemia it is the ligand not the receptor which is faulty. This has emerged from studies carried out by Mahley and colleagues, and reviewed by Havel, ${ }^{22}$ following the original observation of Utermann et al that apoE is polymorphic. ${ }^{23} \mathrm{By}$ isoelectric focusing of delipidated VLDL ${ }^{24}$ it can be shown that most of the population is homozygous or heterozygous for isomorphs apoE $E_{3}$ or $E_{4} \cdot{ }^{22}$ Nearly all type III patients are, however, homozygous for $\operatorname{apoE}_{2}$, which differs from apoE $E_{3}$ and $E_{4}$ by the substitution of cysteine for arginine at position 158 in their respective amino acid sequences. Chylomicron and VLDL remnants bearing $a_{0} E_{2}$ fail to bind to receptors which recognise only the normal apoE isomorphs. As a result remnant particles accumulate in plasma, giving a characteristic "broad $\beta$ " pattern on lipoprotein electrophoresis. Correct diagnosis of this condition is important since treatment with an appropriate diet and clofibrate often results in complete normalisation of serum lipids.

\section{Molecular cloning of apoprotein genes}

Recognising the importance of genetic factors in atherosclerosis molecular biologists have now started to apply their techniques to the identification of apoprotein genes. The first to be cloned was the gene for apoA-I.25 26 and having achieved this the two groups involved started to investigate patients with lipoprotein disorders. Karathanasis et al discovered a polymorphism of the apoA-I gene in two sisters with premature atherosclerosis associated with absence of apoA-I and apoC-III from plasma ${ }^{27}$ and went on to show that the apoA-I and C-III genes are adjacent, ${ }^{28}$ and that the defect responsible for the congenital absence of apoA-I and C-III was an abnormal insertion of DNA in the coding region of the apoA-I gene. ${ }^{29} \mathrm{~A}$ different polymorphism of the apoA-I gene has been shown to be common in hypertriglyceridaemic patients, ${ }^{30}$ but this does not appear to be associated with any detectable abnormalities of apoprotein metabolism and its clinical significance remains to be determined, as discussed elsewhere. ${ }^{31}$ The apoE gene has also been cloned, ${ }^{32}$ and it seems likely that suitable cDNA probes will soon be available for all the apoprotein genes which encode apoproteins of known amino acid sequence. It is also probable that the gene for the LDL receptor will be cloned in the not too distant future, although it may take longer to do the same for $\mathrm{apoB}_{100}$, a very large protein which has not yet been sequenced.

\section{Conclusions}

Quantitative analyses of apoA-I and apoB in plasma appear to provide additional information to that obtained by simply measuring serum lipids and may eventually replace the latter as criteria of coronary heart disease risk. This applies particularly to LDLapoB which seems to be a hitherto unrecognised but important risk factor. Qualitative analysis of apoE phenotypes by isoelectric focusing of VLDL is also useful if type III hyperlipoproteinaemia is to be correctly diagnosed. Finally, the increasing impact of molecular biology on medicine could result in the analysis of apoprotein genes becoming a relatively common investigation in lipid clinics and screening centres. If so, this would result in better delineation of the role of genetic factors in individuals with hyperlipidaemia and enable appropriate therapeutic measures to be instituted earlier and more emphatically. The hope that such measures will avert or delay the onset of premature atherosclerosis and coronary heart disease has gained considerable support from the recently published results of the Lipid Research Clinics Coronary Primary Prevention Trial. ${ }^{33} 34$ 


\section{References}

1 Fredrickson DS, Levy RI, Lees RS. Fat transport in lipoproteins - an integrated approach to mechanisms and disorders. $N$ Engl $f$ Med 1967; 276: 148-56.

2 Davignon J, Dufour R, Cantin M. Atherosclerosis and hypertension. In: Genest J, Kuchel O, Hamet P, Cantin $M$, eds. Hypertension; pathophysiology and treatment. New York: McGraw-Hill, 1983: 810-52.

3 Goldstein JL, Brown MS. Lipoprotein receptors: genetic defence against atherosclerosis. Clin Res 1982; 30: 41726.

4 Lippel K, Tyroler HA, Gotto A Jr, et al. Workshop on apolipoprotein quantification. Arteriosclerosis 1983; 3: 452-64.

5 Goldstein JL, Hazzard WR, Schrott HG, Bierman EL, Motulsky AG. Hyperlipidemia in coronary heart disease. 1. Lipid levels in 500 survivors of myocardial infarction. f Clin Invest 1973; 52: 1533-43.

6 Goldstein JL, Schrott HG, Hazzard WR, Bierman EL, Motulsky AG. Hyperlipidemia in coronary heart disease. II. Genetic analysis of lipid levels in $\mathbf{1 7 6}$ families and delineation of a new inherited disorder, combined hyperlipidemia. f Clin Invest 1973; 52: 1544-68.

7 Kannel WB, Castelli WP, Gordon T. Cholesterol in the prediction of atherosclerotic disease. New perspectives based on the Framingham Study. Ann Intern Med 1979; 90: 85-91.

8 Miller NE, Hammett F, Saltissi S, et al. Relation of angiographically defined coronary artery disease to plasma lipoprotein subfractions and apolipoproteins. $\mathrm{Br}$ Med F 1981; 282: 1741-4.

9 Gidez LI, Miller GJ, Burstein M, Slagle S, Eder HA. Separation and quantitation of subclasses of human plasma high density lipoproteins by a simple precipitation procedure. 7 Lipid Res 1982; 23: 1206-23.

10 Maciejko JJ, Holmes DR, Kottke BA, Zinsmeister AR, Dinh DM, Mao SJT. Apolipoprotein A-I as a marker of angiographically assessed coronary artery disease. $N$ Engl f Med 1983; 309: 385-9.

11 Sniderman AD, Wolfson C, Teng B, Franklin FA, Bachorik PS, Kwiterovich PO Jr. Association of hyperapobetalipoproteinemia with endogenous hypertriglyceridemia and atherosclerosis. Ann Intern Med 1982; 97: 833-9.

12 Avogaro P, Bon GB, Cazzolato G, Quinci GB, Belussi F. Plasma levels of apolipoprotein A1 and apolipoprotein B in human atherosclerosis. Artery 1978; 4: 385-94.

13 Avogaro P, Bon GB, Cazzolato G, Quinci GB. Are apolipoproteins better discriminators than lipids for atherosclerosis? Lancet 1979; i: 901-3.

14 Whayne TF, Alaupovic P, Curry MD, Lee ET, Anderson PS, Schechter E. Plasma apolipoprotein B and VLDL-, LDL-, and HDL-cholesterol as risk factors in the development of coronary artery disease in male patients examined by angiography. Atherosclerosis 1981; 39: 411-24.

15 Avogaro P, Cazzolato G, Bon GB, Belussi F, Quinci GB. Values of apoA-I and apoB in humans according to age and sex. Clin Chim Acta 1979; 95: 311-5.

16 Avogaro P, Bon GB, Cazzolato G, et al. Variations in apolipoprotein $B$ and $A 1$, during the course of myocardial infarction. Eur $\mathcal{F}$ Clin Invest 1978; 8: 121-9.

17 Ishikawa T, Fidge N, Thelle DS, Forde OH, Miller NE.
The Tromsø Heart Study: serum apolipoprotein AI concentration in relation to future coronary heart disease. Eur $\mathcal{F}$ Clin Invest 1978; 8: 179-82.

18 Sniderman A, Shapiro S, Marpole D, Skinner B, Teng B, Kwiterovich PO Jr. Association of coronary atherosclerosis with hyperapobetalipoproteinemia [increased protein but normal cholesterol levels in human plasma low density ( $\beta$ ) lipoproteins]. Proc Natl Acad Sci USA 1980; 77: 604-8.

19 Sniderman A, Teng B, Jerry M. Determination of B protein of low density lipoprotein directly in plasma. $\mathcal{F}$ Lipid Res 1975; 16: 465-7.

20 Hulley SB, Rosenman RH, Bawol RD, Brand RJ. Epidemiology as a guide to clinical decisions. The association between triglyceride and coronary heart disease. $N$ Engl f Med 1980; 302: 1383-9.

21 Brown MS, Goldstein JL, Fredrickson DS. Familial type 3 hyperlipoproteinemia (dysbetalipoproteinemia). In: Stanbury JB, Wyngaarden JB, Fredrickson DS, Goldstein JL, Brown MS, eds. The metabolic basis of inherited disease. 5th ed. New York: McGraw-Hill, 1983: 655-71.

22 Havel RJ. Familial dysbetalipoproteinemia. New aspects of pathogenesis and diagnosis. Med Clin North Am 1982; 66: 441-54.

23 Utermann G, Hees M, Steinmetz A. Polymorphism of apolipoprotein $\mathrm{E}$ and occurrence of dysbetalipoproteinaemia in man. Nature 1977; 269: 604-7.

24 Warnick GR, Mayfield C, Albers JJ, Hazzard WR. Gel isoelectric focusing method for specific diagnosis of familial hyperlipoproteinemia Type 3. Clin Chem 1979; 25: $279-84$.

25 Shoulders CC, Baralle FE. Isolation of the human HDL apoprotein AI gene. Nucleic Acids Res 1982; 10: 4873-82.

26 Breslow JL, Ross D, McPherson J, et al. Isolation and characterization of cDNA clones for human apolipoprotein A-I. Proc Natl Acad Sci USA 1982; 79: 6861-5.

27 Karathanasis SK, Norum RA, Zannis VI, Breslow JL. An inherited polymorphism in the human apolipoprotein A-I gene locus related to the development of atherosclerosis. Nature 1983; 301: 718-20.

28 Karathanasis SK, McPherson J, Zannis VI, Breslow JL. Linkage of human apolipoproteins A-I and C-III genes. Nature 1983; 304: 371-3.

29 Karathanasis SK, Zannis VI, Breslow JL. A DNA insertion in the apolipoprotein A-I gene of patients with premature atherosclerosis. Nature 1983; 305: 823-5.

30 Rees A, Shoulders CC, Stocks J, Galton DJ, Baralle FE. DNA polymorphism adjacent to human apoprotein A-I gene: relation to hypertriglyceridaemia. Lancet 1983; i: 444-6.

31 Thompson G, Soutar A. Genetic polymorphism and plasma lipoproteins. Nature 1983; 301: 658.

32 Breslow JL, McPherson J, Nussbaum $\mathrm{AL}$, et al. Identification and DNA sequence of a human apolipoprotein E cDNA clone. F Biol Chem 1982; 257: 14639-41.

33 Lipid Research Clinics Program. The Lipid Research Clinics Coronary Primary Prevention Trial results. I Reduction in incidence of coronary heart disease. $\mathcal{F A M A}$ 1984; 251: 351-64.

34 Lipid Research Clinics Program. The Lipid Research Clinics Coronary Primary Prevention Trial results. II The relationship of reduction in incidence of coronary heart disease to cholesterol lowering. $\mathcal{F A M A} 1984 ; 251$ : 365-74. 